\title{
Schizophrenia, Cancer and Obstetric Complications in an Evolutionary Perspective-An Empirically Based Hypothesis
}

\author{
Antonio Preti ${ }^{1}$ and Daniel R. Wilson ${ }^{2}$ \\ ${ }^{1}$ Centro Medico Genneruxi, via Costantinopoli 42, Cagliari, Italy \\ ${ }^{2}$ Creighton University Medical Center, Omaha, NE, USA
}

Objective Patients diagnosed with schizophrenia have reduced fecundity and premature mortality (both accidental and violent) with no obvious compensatory advantages among kin. The prevalence of the disorder is around $0.7 / 1 \%$, higher than the expected prevalence of spontaneous mutations. Genes favoring schizophrenia may have been positively selected in the environment of evolutionary adaptation. Literature on potential adaptive genes is reviewed within an evolutionary framework.

Methods Literature search on major scientific search engine (PubMed/Medline, Ovid/PsychInfo) on papers aimed at investigating potential pathways justifying a mutation-selection balanced model. Findings are presented with a narrative touch to favor readability and understanding.

Results Reduced incidence of cancer in both patients diagnosed with schizophrenia and their siblings was reported worldwide. Such findings are notable given higher cancer risk factors in schizophrenia, i.e., smoking, alcohol abuse, obesity, poor diet, and poor adherence to therapy. Some genes involved in cancer proliferation might as well confer protective advantage in immune-surveillance, inflammation, vascular proliferation or apoptosis that otherwise will adversely affect early neurodevelopment.

Conclusion Evidence that reduced risk of certain somatic diseases is associated with schizophrenia is quite significant to progress in the evolutionary epidemiological analysis of psychopathology.

Psychiatry Investig 2011;8:77-88

Key Words Schizophrenia, Etiology, Evolutionary epidemiology, Obstetric complications, Cancer, Immune system.

\section{INTRODUCTION}

Recently Joo and co-workers ${ }^{1}$ reported an association between single nucleotide polymorphisms in the $\mathrm{V}$-akt murine thymoma viral oncogene homolog 1 (AKT1) gene and risk of obstetric complications in a large sample $(n=180)$ of patients diagnosed with schizophrenia. The findings were open to interpretation, since they were statistically significant in female patients only and did not survive a correction for multiple testing. However, they add to a growing literature showing links between genes, schizophrenia and risk for somatic illness are more complicated than currently thought.,3 The role of obstetric complications in schizophrenia is still debated. ${ }^{4}$ Meta-

Received: April 27, 2010 Accepted: October 12, 2010

Available online: December 15, 2010

$\bowtie$ Correspondence: Daniel R. Wilson, MD, PhD

Professor \& Chairman of Psychiatry, Professor of Anthropology, Creighton University Medical Center, 3528 Dodge Street, Omaha, NE 68131, USA

Tel: +1-402-345-8828, Fax: +1-402-345-8815

E-mail: wilson@creighton.edu

(a) This is an Open Access article distributed under the terms of the Creative Commons Attribution Non-Commercial License (http://creativecommons.org/licenses/by$\mathrm{nc} / 3.0$ ) which permits unrestricted non-commercial use, distribution, and reproduction in any medium, provided the original work is properly cited. analyses generally establish a link between obstetric complications and schizophrenia. ${ }^{5}$ Likewise, the suggested reduced risk of cancer in patients diagnosed with schizophrenia is still debated. ${ }^{6,7}$ We think that an evolutionary epidemiological analysis can help better assess these issues. ${ }^{8}$

Evolutionary epidemiology looks for explanation of the persistence of genetically based traits that are maladaptative in terms of survival and fertility. ${ }^{9} 10$ Schizophrenia is a serious, chronic disorder, which negatively impacts the lives of affected patients, their families as well as society at large. The clinical course is typified by highly recurrent acute episodes with chronic impairment of social, vocational, and personal well-being. ${ }^{11-13}$ The costs for patients, their families and society are huge. ${ }^{14,15}$ More complete knowledge of the etiology of this disorder might lead to earlier detection of symptoms, more effective treatments and, ideally, directly preventative interventions. Such a complete understanding will entail not only analyses of complex ontogeny but also more intensive study of the phylogenetics of schizophrenia.

Recent systematic meta-analyses of studies of the epidemiology of schizophrenia reported a median incidence of 15.2/ 
100,000 persons $(80 \% \mathrm{CI}=7.7-43.0)$, and a median prevalence of $4.0 / 1,000$ persons $(80 \% \mathrm{CI}=1.8-11.6)$, with a lifetime morbidity risk of 7.2/1,000 persons. ${ }^{16}$ The risk is higher among males than females, with a risk ratio $=1.4 / 1$.

Family, twin, and adoption studies of schizophrenia confirm a significant but not complete hereditary basis. Odds ratio of familial aggregation of schizophrenia is quite high, on average 6 to $15 .^{17}$ In adoption, the risk is consistently higher in biological versus adoptive clusters. ${ }^{18}$ In twins, the risk is higher among monozygotic than dizygotic pairs. Genetic heritability attributable to non-shared environment is estimated at $81 \%$, with a scant $11 \%$ attributable to environmental effects shared by the members of a twin pair. ${ }^{19,20}$

However, the genetics of schizophrenia remain far from clear. According to a synthesis prepared by Gottesman and Erlenmeyer-Kimling, ${ }^{21}$ prevalence is consistently higher among first-degree relatives of patients-from $6 \%$ of parents to $13 \%$ of offspring. However, up to $63 \%$ of patients have no first- or second-degree relative with the disorder. Moreover, the prevalence of schizophrenia is $48-53 \%$ among monozygotic twins (as against $15-17 \%$ in dizygotic twins).

Additional factors have been reported to be involved in the etiology and developmental onset of schizophrenia, notably place or time of birth, infections during pre- and peri-natal development, obstetric complications during pregnancy or labor (Table 1). Nevertheless, a family history of psychosis is still by far the strongest predictor of schizophrenia in a given subject. ${ }^{22-24}$

\section{What is schizophrenia, really?}

Despite a century of investigation, diagnosis of schizophrenia relies solely on clinical evaluation of symptoms, with no reliable laboratory test to distinguish affected patients from healthy people. Indeed, there is good evidence for global alterations in brain structure and subtle abnormalities in physiological and neurochemical functioning, but few are specific to schizophrenia or have sufficient effect size to allow diagnosis differentiation. ${ }^{25}$ Over time, this difficulty has led to increasingly nihilistic positions, such as claims that schizophrenia is not a distinct or coherent nosological entity but an epistemological delusion without a real basis in nature. ${ }^{26}$ Others propose to subsume schizophrenia into a more general class of psychosis, or meld it within an even more general affective-psychotic continuum. ${ }^{27-29}$ Clearly, lack of external validators seriously hampers the investigation of the epidemiological, clinical and neurobiological correlates of the disorder.

\section{MORBIDITY AND MORTALITY IN SCHIZOPHRENIA}

Current criteria for diagnosis of schizophrenia refer to a prototypical condition subdivided into variants based on associate symptoms, clinical course, and response to treatment, among other considerations. ${ }^{30}$ Patients diagnosed with schizophrenia by current criteria suffer a higher risk of premature mortality-they die much earlier on a modal basis compared to the life expec-

Table 1. Factors related to the risk of schizophrenia in adulthood

\begin{tabular}{|c|c|c|}
\hline \multirow[t]{3}{*}{ Place/Time of birth } & Higher incidence associated to urbanization & Ref. $168,169,170$ \\
\hline & Higher incidence associated to migration & Ref. $171,172,173$ \\
\hline & Slight excess in winter/spring born & Ref. $23,174,175$ \\
\hline \multirow[t]{5}{*}{ Infections } & Influenza & Ref. $176,177,178$ \\
\hline & Rubella & Ref. 179 \\
\hline & Poliovirus & Ref. 180 \\
\hline & Toxoplasmosis & Ref. 181,182 \\
\hline & CNS infections & Ref. 183,184 \\
\hline \multirow[t]{4}{*}{ Pre-/Perinatal factors } & Famine & Ref. $185,186,187$ \\
\hline & Maternal stress by flood & Ref. 188 \\
\hline & Maternal depression & Ref. 189 \\
\hline & Other maternal stress & Ref. 190,191,192 \\
\hline \multirow[t]{4}{*}{ Obstetric complications } & Rh incompatibility & Ref. 115,116 \\
\hline & Hypoxia & Ref. 5,193,194 \\
\hline & CNS damage/Low birth weight & Ref. $195,196,197$ \\
\hline & Preeclampsia & Ref. 198,199 \\
\hline \multirow[t]{3}{*}{ Family history } & Significant familial aggregation & Ref. $22,23,24$ \\
\hline & Increased risk in biological vs. adoptive parents & Ref. 18 \\
\hline & Higher risk in monozygotic vs. dizygotic twins & Ref. $19,200,201$ \\
\hline
\end{tabular}

78 Psychiatry Investig 2011;8:77-88 
tancy of the general population. These risks are higher for both natural ${ }^{13,31}$ and violent causes, ${ }^{32}$ particularly suicide. ${ }^{33}$

Higher risk of premature mortality in patients with schizophrenia depends on increased incidence of somatic diseases in these patients, largely as a consequence of psychopathology. ${ }^{12}$ A higher risk has been reported for infections such as tuberculosis and virus disease ${ }^{34-36}$ respiratory tract diseases, ${ }^{37}$ nutritional and metabolic disorders ${ }^{38-40}$ and cardiovascular disease. ${ }^{41,42}$ Even adjusted mortality due to poor dental hygiene among persons poses an important burden on patients suffering schizophrenia. ${ }^{43,44}$ The main causes of greater rates and severity of somatic diseases in patients diagnosed with schizophrenia include unhealthy lifestyle and poor adherence to treatment, notably medication. ${ }^{45,46}$ Conversely, the often-significant adverse consequences of prescribed antipsychotic therapy directly increase a number of serious illnesses, notably the 'metabolic syndrome. ${ }^{47-49}$ Yet some recent studies and meta-analyses indicate patients diagnosed with schizophrenia have a reduced incidence of cancer and neoplasms. ${ }^{7,50-53}$ Such a reduced risk of cancer in patients strongly suggests that somatic factor(s) co-occuring with schizophrenia are protective against cancer.

\section{Inclusive fitness in schizophrenia}

From an evolutionary point of view, survival is not merely due to adaptation to the environment. In Darwinian terms, individual fitness refers to differential replication of one's genes in the next generation, that is, mating success. The ability to rear offspring is essential in achieving individual fitness. Ultimately, individual fitness entails:

1) securing nutrients and other resources for survival,

2) avoidance of death before reproduction, and

3) finding mates to beget offspring, and then

4) rearing of them until sexual maturity and reproduction of the lineage.

The increase in the number of one's genes in subsequent generations also includes non-offspring kin, as a function of the percentage of genes by direct descent from a common ancestor. This is inclusive fitness, which refers to the total replication of genes in the subsequent generation via both direct (offspring) and indirect (kin) carriers. ${ }^{54,55}$

Some older studies reported a trend towards higher fertility rates in patients' relatives. ${ }^{56,57}$ On the other hand, most studies have reported lower fertility rates in schizophrenia, ${ }^{58-60}$ and no compensatory fertility in relatives. ${ }^{61,62}$ Clinical experience is that patients suffering from severe mental disorders tend to have a lower chance of mating-social incapacities form barriers to the tasks of finding a partner, having children, and then rearing them to maturity. The practice of detaining patients with severe mental disorders in locked mental health hospitals surely contributed to reduce their reproductive opportunities. Studies on this non-secondary aspect of the life of patients with schizophrenia are pending in countries where provision of care for patients with mental disorders is covered by networks of community mental health outpatient centers that have expanded as hospitals closed. ${ }^{63}$

The paradox of a disorder with a general population prevalence of nearly $1 \%$, with a robust genetic basis, but lower fecundity and no fertility compensatory advantage in relatives, taken together suggests that the genetic aberration linked to this illness must also carry with it a heretofore unrecognized evolutionary advantage. ${ }^{64}$ As yet, attempts to identifying any unrecognized evolutionary advantages have been challenging and largely unsatisfactory. However, factors linked to reduced risk of cancer could have been a powerful selective advantage in phylogeny.

\section{CANCER AND SCHIZOPHRENIA}

In a recent meta-analysis, Catts et $\mathrm{al}^{7}{ }^{7}$ found that the overall cancer incidence rates in patients suffering from schizophrenia were not significantly higher than those in the general population. This was despite the high load of risk factors for cancer among patients with schizophrenia, including smoking, alcohol abuse, obesity, poor diet, and non-adherence to medical advice. Indeed Catts et al. ${ }^{7}$ found a reduced risk of colorectal cancer, malignant melanoma, and prostate cancer among patients with schizophrenia compared to the general population, and a reduced impact of smoking on lung and bladder cancer risks.

Remarkably, that patients suffering from schizophrenia have a lower risk of cancer is a long-recognized feature of the disorder, ${ }^{65}$ with reports as early as $1909,{ }^{66}$ although such reports do not constitute a consensus. ${ }^{67}$ While important negative results have been reported, other surveys describe an enhanced, rather than decreased, cancer risk among patients diagnosed with schizophrenia. ${ }^{6,68}$ Nevertheless, patients with schizophrenia tend to be early, heavy, and long-term smokers of cigarettes; ${ }^{69,70}$ so, much higher rates of cancer among persons with schizophrenia ought to be evident given such exposure to a recognized risk factor for many types of cancer. ${ }^{71}$ Beyond smoking as a major risk factor, such patients are less able to pay proper attention to other broad health factors, notably a balanced diet or regular exercise. Moreover, high rates of substance use disorder that cooccur with schizophrenia are an additional source of cancer risk. $^{72-74}$

Smoking, alcohol use, and life-style differences are not the only explanations for the distinct differences in cancer prevalence noted within the general population. Exposure to carcinogenic chemical compounds in the workplace could represent a greater risk factor for some types of cancer than smoking or eating less fruit and vegetables than suggested by current 
health guidelines. ${ }^{75,76}$ If so, persons with schizophrenia, by inference from their much higher rates of unemployment, may be expected to have fewer cancers. Similarly, some have posited that antipsychotic pharmacotherapy itself may have both direct $^{77,78}$ and indirect anticancer effects (such as hormonal modulation by dopamine). These might contribute to the lower rate of cancer occurrence in schizophrenia. ${ }^{79,80}$ Indeed, perhaps the best evidence of lower risk in patients with schizophrenia is with prostate cancer, ${ }^{81}$ a condition considerably influenced by hormones affected by antipsychotic drugs. In the aging male, prostate cancer occurs more commonly amid rising levels of estrogen and decreasing levels of androgen. ${ }^{82}$ The prolactin-inducing property of most antipsychotic drugs has a subsequent negative feedback on estrogen levels. ${ }^{83}$ This might reduce risk of prostate cancer in patients treated with antipsychotic drugs, despite representing per se a risk factor for other types of cancer. ${ }^{84}$ On the other hand, rates of breast cancer are increased in women with schizophrenia but at a rate lower than expected from known risk factors; among others, null-parity, obesity, poor diet, and hyperprolactinemia related to antipsychotic medication exposure.?

The pathways to reduced risk of cancer in schizophrenia are manifold. Cancers are conditions often occurring in later life. Causes of death exclude each other: someone who dies by suicide cannot die by cancer. Since patients with schizophrenia often die at a younger age than the general population, they may not have the time to develop certain cancers. Psychiatric patients might be less likely to be screened for cancer, or may be more frequently lost in follow-up, and also were known to be less likely to report physical symptoms, ${ }^{85}$ though patients rarely ignore advanced symptoms of cancer, such as pain. Finally, the epigenetics and epiphenemics of schizophrenia itself may confer some kind of genetic protection against cancer.

\section{A role for genetics}

A recent report from Israel offers clear evidence that the lower risk of cancer extends to patients' close kin. Both the parents and siblings of subjects with schizophrenia had a statistically significant lower risk of cancer, with the clearest evidence noted in reduced cancers of the breast and prostate.$^{86}$ These Israeli findings parallel a prior publication of a national cohort of individuals born in Finland between 1940 and 1969 who were treated for schizophrenia between 1969 and $1991 .{ }^{6}$ However, another population study carried out on the Danish Central Registries on Psychiatry and Cancer reported negative findings. ${ }^{87}$

With respect to the Israeli study, the lower risk of morbidity for cancer in both index cases and blood relatives strongly points to a genetic influence. The patient group, less likely to have a job, is perhaps less exposed to chemical carcinogenic compounds and/or may gain some benefit from as yet unknown protective effects of antipsychotic medications. However, such mechanisms cannot account for the reduced risk in their bloodkin. It is unclear if patients' relatives are more health-conscious than the affected kin, i.e., smoke less than the general population, as this has not been studied. It is pertinent that the Israeli study did tally schizophrenia diagnoses in the sample of relatives and the exclusion of those with schizophrenia did not change the findings. Healthy parents and siblings of patients with schizophrenia still showed a lower risk of cancer than the comparison group.

There are few doubts that genetics plays a relevant role in increasing, or decreasing, the risk of cancer within components of the general population. ${ }^{88-90}$ Some studies suggest very simple genetic mechanisms may have a major role in many familial cancers: ${ }^{91,92}$ the Lynch Syndrome was perhaps the first confirmation of a mendelian cancer, in the colon. ${ }^{93,94}$ So too, yet unknown genetic factors linked to the reduced risk of cancer in schizophrenia could have a role in the etiology of the disorder.

\section{GENETICS, OBSTETRIC COMPLICATIONS, AND SCHIZOPHRENIA: THE MISSING LINK?}

The etiology of schizophrenia remains unknown, and its genetics is quite puzzling: heritability is $70-85 \%$, yet $60 \%$ of the people diagnosed with schizophrenia have neither a first, nor a second-degree affected relative. ${ }^{21,95}$ Moreover, concordance in twins oscillates between 15 and $58 \%{ }^{21,96}$ indicates some role for post-translational epigenetic factors. ${ }^{97,98}$ Large-scale surveys have identified a wide range of susceptibility genes, ${ }^{99}$ but the specificity of these genes to schizophrenia is questionable, and attempts to replicate findings were often unsuccessful. ${ }^{100,101}$ While it is unlikely a single gene is responsible for schizophrenia, the issue is clouded by vast problems in proper clinical description of a true epigenetic phenotype that is separable from similar acquired syndromes. ${ }^{8}$

Drawing from past formulations, ${ }^{10,64}$ an oligogenic, mutationselection balance model has been proposed to explain inconsistencies in the identification of susceptibility genes in schizophrenia. In this model, a relatively small number of alternative alleles are maintained because their net fitness effects balance each other, so the alleles are not lost by chance or genetic dri$\mathrm{ft} .{ }^{102,103}$ Such a mechanism could imply some gene-environment interaction, ${ }^{104,105}$ whereby a genetic profile is associated with an enhanced risk of suffering from adverse events on a neurodevelopment basis (Figure 1).

Studies of both animals and humans point to the possibility environmental events might impact genetic predisposition to abnormal reactions after CNS lesion, causing deviations in the natural course of brain maturation that may result in neuropsy- 
chiatric disorders. ${ }^{106-110}$ Pre-/Peri-natal complications are thought to disrupt normal fetal brain development, thus disorganizing both the cerebral micro-architecture and neural network interlacement. Pre-/Peri-natal complications most often associated with schizophrenia in general lead to hypoxic-ischemic damage. ${ }^{5}$ However, major fetal brain anoxia - likely to result from severe obstetric complications - generally leads to death or to marked motor impairment. ${ }^{111,112}$ Therefore, we infer that some brain-protecting gene would be necessary to balance the brain-damaging impact of severe obstetric complications: whenever obstetric complications occur, schizophrenia would develop only in the presence of the protective gene. ${ }^{105}$ However, even less severe obstetric complications may cause deviation in neurodevelopment when alleles enhancing the impact of these obstetric events are present, and again the co-occurrence of brain-protecting gene would prevent the worst consequences of the resulting brain damage (death or severe cognitive or motor impairment).

A link between obstetric complications and schizophrenia is now well established and the effect is small, but consistent. ${ }^{113,114}$ Past studies found that certain epigenetic conditions increasing the risk of obstetric complications are also associated with a higher risk of schizophrenia, e.g., Rh-incompatibility. ${ }^{115,116}$ Obstetric complications also tend to recur within families and cluster in families with a larger number of subjects diagnosed with schizophrenia. ${ }^{117}$ In addition, mothers of children who later suffer from schizophrenia themselves have enhanced risk of unfavorable outcome in pregnancies other than the index case. ${ }^{118}$ Conversely, siblings of patients with schizophrenia incur greater frequency and severity of pregnancy and birth complication than do healthy controls. ${ }^{119}$

Such evidence suggests the genetics of schizophrenia might be explained, in part, by the related genetics of conditions that increase risk of obstetric complications. ${ }^{105,120}$ Even where there is seemingly equal exposure to risk, as in the case of twins, one twin may actually be more at risk. Such variations may help explain the incomplete concordance of schizophrenia in identical twins. Indeed, McNeil and coworkers ${ }^{121}$ noted that labor complications in monozygotic twins were significantly more frequent in twins discordant for schizophrenia.

Thus a wide range of mechanisms - inflammatory, immune, and/or vascular basis - may be processes etiogenic of schizophrenia. These range from initial pre/peri-natal brain insults, to neuronal reorganization and synaptic plasticity in adolescence (the "second hit" in Figure 1), and finally to the onset of psychosis. ${ }^{105,122,123}$ Though heavily genetic, schizophrenia is also subject to considerable environmental influence. ${ }^{104,105}$ But, what kind of genes could be involved, both related to cancer and expressing some protective effect on the neurodevelopment?

\section{POTENTIAL PATHWAYS IN THE REDUCED RISK OF CANCER IN SCHIZOPHRENIA}

In their attempt to explain the lower cancer risk in parents and siblings of patients with schizophrenia, Levav and co-work$\mathrm{ers}^{86}$ hypothesized a role for the tumor suppressor p53 gene. ${ }^{124,125}$ This gene is but the first of the many with possible implications for reduced risk of cancer in schizophrenia. There are other candidate genes, including:

-Adenomatous polyposis coli gene, tumor suppressor that is significantly associated with schizophrenia; ${ }^{126}$

-The fragile site, aphidicolin type, common, fra(6)(q21) (FRA6F), a site of unusual chromosomal fragility, is likely to carry a tumor suppressor gene in a region that also maps to a gene

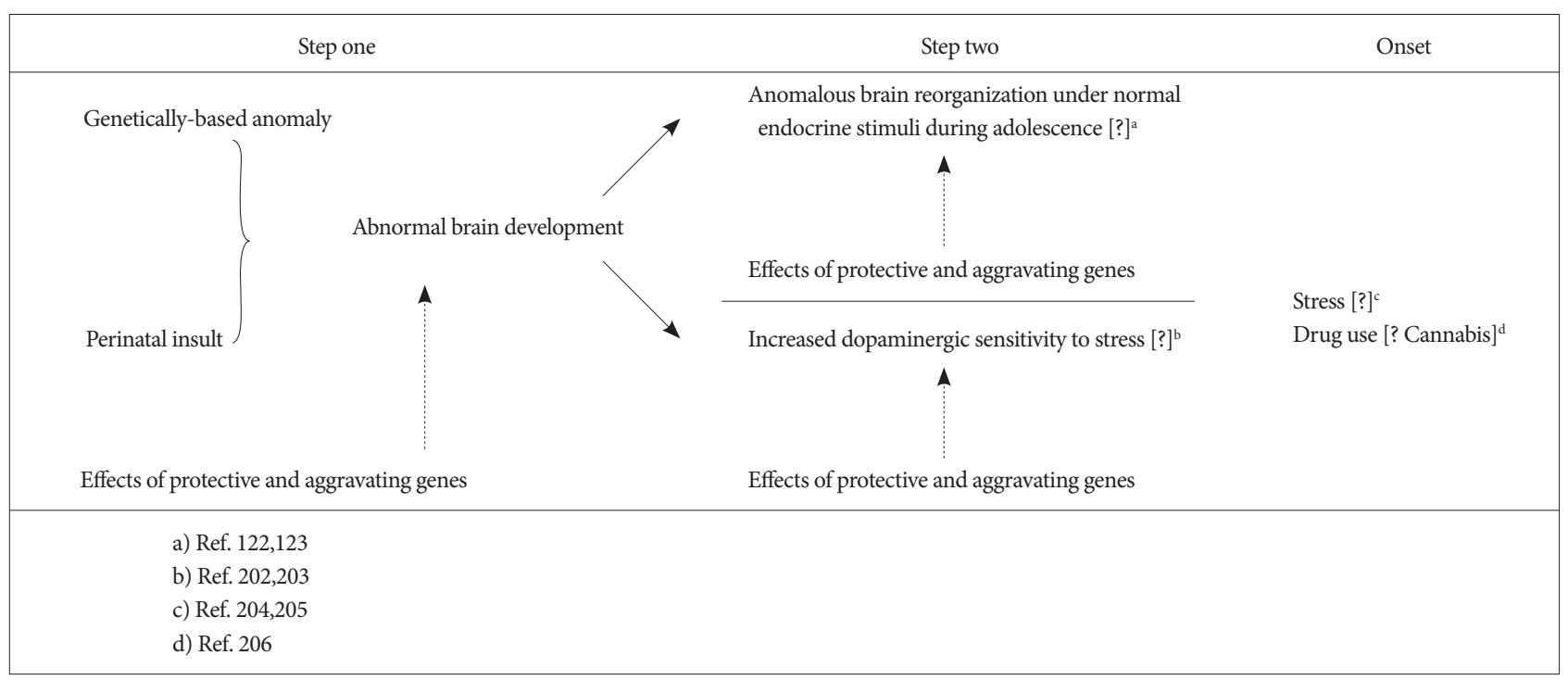

Figure 1. The "two/three-hits" neurodevelopmental hypothesis of schizophrenia. 
linked to hereditary schizophrenia; ${ }^{127}$

-Phosphatidylinositide 3-kinase-protein kinase B pathway genes are involved in cellular growth and proliferation. These activities are reduced in schizophrenia, which may logically protect against cancer; ${ }^{2}$

-Neuregulin-I/ErbB signalling system genes modulate cell proliferation, migration, differentiation, and survival or apoptosis. ${ }^{128,129}$ Neuregulin-I attenuated signaling is seen in animal models of schizophrenia; ${ }^{128,130}$

-Bombesin-activated pathway genes have bombesin-like peptides that act as growth factors in the pathogenesis of several human cancers. ${ }^{131}$ Patients with schizophrenia have lower levels of bombesin than do non-schizophrenic subjects; ${ }^{132}$

-Neurotensin genes implied in the activity of antipsychotic drugs. ${ }^{133}$ Neurotensin also down-regulates neuropeptides autocrine growth factors active in cancer lines.

Additional mechanisms may be involved. MicroRNAs - noncoding RNA molecules thought to regulate expression of many mRNAs - are implicated in the etiology of several types of cancer and expressed at a lower level in patients with schizophrenia. ${ }^{134}$ Likewise, short tandem repeat (STR) replacements in untranslated sequence (UTR), putatively involved in both schizophrenia and cancer. ${ }^{135}$

\section{THE ROLE OF DEVIANCE IN NEURODEVELOPMENT}

Apart from cancer, people with schizophrenia not only have reduced prevalence of diabetes mellitus type $1^{136}$ and rheumatoid arthritis ${ }^{137,138}$ but both conditions are influenced by genes that control immune and inflammatory systems - genes that may also influence obstetric complications on neurodevelopment.

Immune-mediated conditions share with schizophrenia a propensity to atypical handedness (increased left-handedness and/or mixed-handedness), which is associated with many neurodevelopmental disorders. ${ }^{139-141}$

Additionally, a wide range of genes can influence, positively or negatively, the chances of cancer development. These include genes involved in control of immune-surveillance, ${ }^{142,143}$ inflammation, ${ }^{144-146}$ vascular proliferation, ${ }^{147-149}$ and apoptosis. ${ }^{128,150}$ Most of these genes are also involved in neurodevelopment, guiding neuron proliferation and rearrangement.

Nicodemus et al. ${ }^{151}$ reported four genes - AKT1, brain-derived neurotrophic factor (BDNF), glutamate receptor 3 (GRM3), and dystrobrevin-binding protein 1 (DTNBP1)-are potentially involved in hypoxia/ischemia and/or the integrity of cerebrovasculature structures. These four genes are expressed in a nonrandom fashion among patients with schizophrenia who experienced obstetric complications during pregnancy. Moreover, these genes have a demonstrable neuroprotective role. ${ }^{152}$
The Nicodemus study is the first to assess a plausible hypothesis of gene-by-environment interaction in schizophrenia risk.

All these genes might exert their effects through the wellknown mechanisms of pleiotropy and epistasis, ${ }^{153}$ as the same genes that protect the brain from excessive perinatal damage may also both foster later development of schizophrenia yet protect against cancer.

\section{EVIDENCE FOR ADAPTIVE EVOLUTION OF GENES INVOLVED IN SCHIZOPHRENIA}

Crespi and co-workers ${ }^{154}$ found evidence of positive selection of genes involved in the etiology of schizophrenia. HapMap-based analyses showed evidence for positive selection on 14 genes associated with schizophrenia. Stronger statistical evidence was noted for DTNBP1 and the GRM3. Positive selection was found in additional 4 genes in the human - compared to chimpanzee- or primate-origin lineages. These genes are neuregulin 1 (NRG1), proteolipid protein 1 (PLP1), tenascin XB (TNXB), tumour protein p53 (TP53). Also, the 'disrupted in schizophrenia' gene (DISC1) showed positive selection in the human lineage, with evidence of acceleration in the coding region repeatedly associated with schizophrenia. ${ }^{154}$

More recently, a meta-analysis of the SchizophreniaGene database found 8 potential candidate genes whose polymorphisms are statistically associated with schizophrenia. ${ }^{155}$ Some correlated to enhanced risk of schizophrenia in carriers: TP53, dopamine receptor D4 (DRD4), 5,10-methylenetetrahydrofolate reductase (MTHFR), protein phosphatase 3 [formerly 2B] catalytic (PPP3CC), and gamma-aminobutyric acid A receptor, beta (GABRB2). Conversely, others were associated with reduced risk of schizophrenia: D-amino acid oxidase (DAO), solute carrier family 6 member 4 (SLC6A4, also known as 5-hydroxytryptamine transporter or 5-HTT), and interleukin 1 and beta proprotein (IL1B). This is fully compatible with the hypothesis that both protective and aggravating genes play a role in the etiology of schizophrenia.

\section{IMPLICATIONS FOR RESEARCH}

Neither reduced risk of cancer nor the recently reported reduced mortality by cerebrovascular incidents ${ }^{13}$ cause genes etiogenic of schizophrenia to persist in the general population. Cancer or stroke typically occur well after sexual maturation and the reproductive cycle so neither should impact inclusive fitness of the individual. Thus, evidence that schizophrenia confers reduced risk of certain somatic diseases, if confirmed, is highly significant information for evolutionary epidemiological analyses. This association is presumably mediated by important genetic 
elements in systems that involve immune-surveillance, inflammation, vascular proliferation or apoptosis. Moreover, the association points to pleiotropic or epistatic etiogenes that not only induce schizophrenia but also confer protective somatic effects evident after the onset of psychosis. Though rather complex as pleiotropy and epistasis ever are, such associations evidently conferred distinct adaptive advantages in the environment of evolutionary adaptation. ${ }^{8}$

Indeed, these genes might have contributed to speciation, by protecting the fetus brain from increasing risk of damage in early environment. Among major factors that confer to the human fetus a higher risk of injury and infection are: large ratio of fetal head to maternal pelvic outlet size, presentation in occipital position (rather than face up, as in the apes), and prolonged labor and delivery in humans compared to other anthropoids. ${ }^{156}$

As delineated in this and prior papers, ${ }^{105,120}$ schizophrenia could only develop when environmental events impacting the fetus in pregnancy and the perinatum (that occur within still to be identified temporal windows), thereby affect specific regions of the developing brain in presence of protective genes which prevent death or severe motor or cognitive impairment. Schizophrenia does not persist because it protects from cancer or stroke, but because genes that offer such somatic protection are essential in successful navigation of earlier developmental phases where schizophrenia arises.

However, it is unlikely schizophrenia has a single etiological cause. It is possible that schizophrenia-like syndromes following obstetric complications merely converge in disrupting mechanisms implicated in other heritable forms of psychoses diagnosable as "schizophrenia" endophenotypes according currently shared criteria. Hemispheric lateralization is one notable example wherein developmental disruptions often give rise to psychosis. ${ }^{157}$ Indeed, obstetric complications often result in abnormal hemispheric specialization ${ }^{158-160}$ of the kind more often reported in schizophrenia. ${ }^{161,162}$

Evolutionary sciences in general and evolutionary psychiatry in particular are often criticized for lack of testable hypotheses. ${ }^{163}$ Yet practical, ethical study protocols are elusive. ${ }^{8}$ Here we have integrated a body of evidence with direct clinical consequences as well as importance to evolutionary interpretation. Moreover and of particular interest to skeptics of evolutionary epidemiological analyses, it is possible to test the pleomorphic and epistatic roles here proposed for genes linked to protection against cancer and schizophrenia.

Patients with schizophrenia should be significantly more likely to screen positive for hereditary disorders linked to increased risk of obstetric complications. ${ }^{105}$ Conversely, persons born with hereditary disorders that may increase risk of obstetric complications may have higher prevalence of schizophrenia in their families. Moreover, persons who both suffer from schizophre- nia and also experienced obstetric complications should have lower rates of some cancers.

Genetic polymorphisms that increase chances of neoplasia should be less common among persons with schizophrenia and their families. Conversely, genetic polymorphisms that decrease chances of neoplasia should be more common among persons with schizophrenia and their families. Patients who suffer from schizophrenia should be found to down-regulate genes and systems that increase cell proliferation, migration, differentiation, and survival or apoptosis, hence increasing the chance of cancer. Finally, the relationships between cancer and schizophrenia may span a multitude of regulatory pathways and genetic polymorphisms. Thus a rational approach should focus on factors that are more likely to moderate the consequences of prenatal and perinatal complications. Here we posit that such specific factors involved in cancer development and proliferation are also likely to be important in the development of schizophrenia.

Some preliminary findings are consisting with these expectations. The most common haplotype block of MET proto-oncogene (MET) is primarily linked to tumor metastasis. This haplotype was found in patients with schizophrenia statistically less often than in healthy controls. ${ }^{164}$ The Matrix metalloproteinase-9 (MMP9), also known as gelatinase B, $92 \mathrm{kDa}$ gelatinase, or 92 Da type IV collagenase, is involved in cancer and cardiovascular disorders. In particular, the functional -1562 C/T polymorphism of the MMP9 gene confer a higher risk of cardiac mortality and more severe progression of some type of cancer: a diminished frequency of the T allele of the MMP9 gene was reported in patients diagnosed with schizophrenia. ${ }^{165}$ It is notable genes specifically disrupted in schizophrenia operate in interacting pathways but most are related to the development of the neural and immune systems. ${ }^{166,167}$

Further investigation of the links between schizophrenia and cancer will reveal much about the etiology of psychosis and will also cast light on a variety of somatic illnesses associated with schizophrenia and cancer through pleomorphic and epistatic mechanisms. The discovery of pathways that lead from pre- and/ or peri-natal insult caused by obstetric complications onto the manifestation of schizophrenia should advance therapeutics as well. Such discoveries may facilitate preventive measures in early development and may also guide screening and treatment for those types of cancer with reduced incidence in schizophrenia. Presently, early evidence is most robust for a role of genes protective in cancer that increase risk of schizophrenia - and vice versa. More expansively, this evolutionary epidemiological approach will likely trace many new and unexpected medicalpsychiatric pleomorphies and epistases.

\section{REFERENCES}

1. Joo EJ, Lee KY, Jeong SH, Roh MS, Kim SH, Ahn YM, et al. AKT1 
gene polymorphisms and obstetric complications in the patients with schizophrenia. Psychiatry Investig 2009;6:102-107.

2. Kalkman HO. The role of the phosphatidylinositide 3-kinase-protein kinase B pathway in schizophrenia. Pharmacol Ther 2006;110:117-134.

3. Preti A. Reduced risk of cancer in schizophrenia: a role for obstetric complications? Acta Psychiatr Scand 2008;118:251-253; author reply 253.

4. Sacker A, Done DJ, Crow TJ, Golding J. Antecedents of schizophrenia and affective illness. Obstetric complications. Br J Psychiatry 1995; 166:734-741.

5. Cannon M, Jones PB, Murray RM. Obstetric complications and schizophrenia: historical and meta-analytic review. Am J Psychiatry 2002;159:1080-1092.

6. Lichtermann D, Ekelund J, Pukkala E, Tanskanen A, Lönnqvist J. Incidence of cancer among persons with schizophrenia and their relatives. Arch Gen Psychiatry 2001;58:573-578.

7. Catts VS, Catts SV, O’Toole BI, Frost AD. Cancer incidence in patients with schizophrenia and their first-degree relatives-a meta-analysis. Acta Psychiatr Scand 2008;117:323-336.

8. Wilson DR, Cory AG. The Evolutionary Epidemiology of Mania \& Depression. New York, NY: Mellen Press; 2008.

9. Stevens A, Price J. Evolutionary psychiatry. A New Beginning. London and New York: Routledge; 1996.

10. Wilson DR. Evolutionary epidemiology. Acta Biotheor 1992;40:87-89.

11. Harrison G, Hopper K, Craig T, Laska E, Siegel C, Wanderling J, et al. Recovery from psychotic illness: a 15- and 25-year international follow-up study. Br J Psychiatry 2001;178:506-517.

12. Leucht S, Burkard T, Henderson J, Maj M, Sartorius N. Physical illness and schizophrenia: a review of the literature. Acta Psychiatr Scand 2007; 116:317-333.

13. Saha S, Chant D, McGrath J. A systematic review of mortality in schizophrenia: is the differential mortality gap worsening over time? Arch Gen Psychiatry 2007;64:1123-1131.

14. Lauber C, Keller C, Eichenberger A, Rössler W. Family burden during exacerbation of schizophrenia: quantification and determinants of additional costs. Int J Soc Psychiatry 2005;51:259-264.

15. Knapp M, Mangalore R, Simon J. The global costs of schizophrenia. Schizophr Bull 2004;30:279-293.

16. McGrath J, Saha S, Chant D, Welham J. Schizophrenia: a concise overview of incidence, prevalence, and mortality. Epidemiol Rev 2008;30: 67-76.

17. Sullivan, PF. The genetics of schizophrenia. PLoS Med 2005;2:e212.

18. Tienari P, Wynne LC, Sorri A, Lahti I, Läksy K, Moring J, et al. Genotype-environment interaction in schizophrenia-spectrum disorder. Longterm follow-up study of Finnish adoptees. Br J Psychiatry 2004;184:216222.

19. Cannon TD, Kaprio J, Lönnqvist J, Huttunen M, Koskenvuo M. The genetic epidemiology of schizophrenia in a Finnish twin cohort. A population-based modeling study. Arch Gen Psychiatry 1998;55:67-74.

20. Cardno AG, Gottesman II. Twin studies of schizophrenia: from bowand-arrow concordances to star wars $\mathrm{Mx}$ and functional genomics. Am J Med Genet 2000;97:12-17.

21. Gottesman II, Erlenmeyer-Kimling L. Family and twin strategies as a head start in defining prodromes and endophenotypes for hypothetical early-interventions in schizophrenia. Schizophr Res 2001;51:93-102.

22. Kendler KS, McGuire M, Gruenberg AM, O'Hare A, Spellman M, Walsh D. The Roscommon Family Study. I. Methods, diagnosis of probands, and risk of schizophrenia in relatives. Arch Gen Psychiatry 1993; 50:527-540.

23. Mortensen PB, Pedersen CB, Westergaard T, Wohlfahrt J, Ewald H, Mors $\mathrm{O}$, et al. Effects of family history and place and season of birth on the risk of schizophrenia. N Engl J Med 1999;340:603-608.

24. Tienari P, Wynne LC, Läksy K, Moring J, Nieminen P, Sorri A, et al. Genetic boundaries of the schizophrenia spectrum: evidence from the Finnish Adoptive Family Study of Schizophrenia. Am J Psychiatry 2003;
160:1587-1594.

25. Keshavan MS, Tandon R, Boutros NN, Nasrallah HA. Schizophrenia, "just the facts": what we know in 2008 Part 3: neurobiology. Schizophr Res 2008;106:89-107.

26. Boyle M. Schizophrenia: A Scientific Delusion? 2 edition (first published in 1990). New York: Routledge; 2002.

27. Craddock N, Owen MJ. The beginning of the end for the Kraepelinian dichotomy. Br J Psychiatry 2005;186:364-366.

28. Peralta V, Cuesta MJ. A dimensional and categorical architecture for the classification of psychotic disorders. World Psychiatry 2007;6:100-101.

29. Crow TJ. Craddock \& Owen vs Kraepelin: 85 years late, mesmerised by "polygenes". Schizophr Res 2008;103:156-160.

30. Jablensky A. Subtyping schizophrenia: implications for genetic research. Mol Psychiatry 2006;11:815-836.

31. Hiroeh U, Kapur N, Webb R, Dunn G, Mortensen PB, Appleby L. Deaths from natural causes in people with mental illness: a cohort study. J Psychosom Res 2008;64:275-283.

32. Harris EC, Barraclough B. Excess mortality of mental disorder. Br J Psychiatry 1998;173:11-53.

33. Palmer BA, Pankratz VS, Bostwick JM. The lifetime risk of suicide in schizophrenia: a reexamination. Arch Gen Psychiatry 2005;62:247-253.

34. Cividini A, Pistorio A, Regazzetti A, Cerino A, Tinelli C, Mancuso A, et al. Hepatitis $C$ virus infection among institutionalised psychiatric patients: a regression analysis of indicators of risk. J Hepatol 1997;27:455-463.

35. Ohta Y, Nakane Y, Mine M, Nakama I, Michitsuji S, Araki K, et al. The epidemiological study of physical morbidity in schizophrenics--2. Association between schizophrenia and incidence of tuberculosis. Jpn J Psychiatry Neurol 1988;42:41-47.

36. Wainberg ML, Cournos F, Mckinnon K, Berkman A. HIV and hepatitis C in patients with schizophrenia. In: Meyer JM, Nasrallah HA, eds. Medical illness and schizophrenia. Washington, DC: American Psychiatric Publishing Inc, 2003, p.115-140.

37. Filik R, Sipos A, Kehoe PG, Burns T, Cooper SJ, Stevens H, et al. The cardiovascular and respiratory health of people with schizophrenia. Acta Psychiatr Scand 2006;113:298-305.

38. Allison DB, Mentore JL, Heo M, Chandler LP, Cappelleri JC, Infante $\mathrm{MC}$, et al. Antipsychotic-induced weight gain: a comprehensive research synthesis. Am J Psychiatry 1999;156:1686-1696.

39. Heiskanen T, Niskanen L, Lyytikäinen R, Saarinen PI, Hintikka J. Metabolic syndrome in patients with schizophrenia. J Clin Psychiatry 2003; 64:575-579.

40. Newcomer JW, Haupt DW, Fucetola R, Melson AK, Schweiger JA, Cooper BP, et al. Abnormalities in glucose regulation during antipsychotic treatment of schizophrenia. Arch Gen Psychiatry 2002;59:337-345.

41. Goff DC, Sullivan LM, McEvoy JP, Meyer JM, Nasrallah HA, Daumit GL, et al. A comparison of ten-year cardiac risk estimates in schizophrenia patients from the CATIE study and matched controls. Schizophr Res 2005;80:45-53.

42. McDermott S, Moran R, Platt T, Isaac T, Wood H, Dasari S. Heart disease, schizophrenia, and affective psychoses: epidemiology of risk in primary care. Community Ment Health J 2005;41:747-755.

43. Friedlander AH, Marder SR. The psychopathology, medical management and dental implications of schizophrenia. J Am Dent Assoc 2002; 133:603-610; quiz 624-625.

44. McCreadie RG, Stevens H, Henderson J, Hall D, McCaul R, Filik R, et al. The dental health of people with schizophrenia. Acta Psychiatr Scand 2004;110:306-310.

45. McCreadie RG; Scottish Schizophrenia Lifestyle Group. Diet, smoking and cardiovascular risk in people with schizophrenia: descriptive study. Br J Psychiatry 2003;183:534-539.

46. Nosé M, Barbui C, Tansella M. How often do patients with psychosis fail to adhere to treatment programmes? A systematic review. Psychol Med 2003;33:1149-1160.

47. Newcomer JW. Antipsychotic medications: metabolic and cardiovascular risk. J Clin Psychiatry 2007;68 Suppl 4:8-13. 
48. Østbye T, Curtis LH, Masselink LE, Hutchison S, Wright A, Dans PE, et al. Atypical antipsychotic drugs and diabetes mellitus in a large outpatient population: a retrospective cohort study. Pharmacoepidemiol Drug Saf 2005;14:407-415.

49. Fontaine KR, Heo M, Harrigan EP, Shear CL, Lakshminarayanan M, Casey DE, et al. Estimating the consequences of anti-psychotic induced weight gain on health and mortality rate. Psychiatry Res 2001;101:277288.

50. Barak Y, Achiron A, Mandel M, Mirecki I, Aizenberg D. Reduced cancer incidence among patients with schizophrenia. Cancer 2005;104: 2817-2821.

51. Cohen M, Dembling B, Schorling J. The association between schizophrenia and cancer: a population-based mortality study. Schizophr Res 2002; 57:139-146

52. Dalton SO, Mellemkjaer L, Thomassen L, Mortensen PB, Johansen C. Risk for cancer in a cohort of patients hospitalized for schizophrenia in Denmark, 1969-1993. Schizophr Res 2005;75:315-324.

53. Grinshpoon A, Barchana M, Ponizovsky A, Lipshitz I, Nahon D, Tal O, et al. Cancer in schizophrenia: is the risk higher or lower? Schizophr Res 2005;73:333-341.

54. Hamilton WD. The evolution of altruistic behaviour. Am Nat 1963;97: 354-356.

55. Hamilton WD. The genetical evolution of social behaviour. J Theor Biol 1964;7:1-52.

56. Lane A, Byrne M, Mulvany F, Kinsella A, Waddington JL, Walsh D, et al. Reproductive behaviour in schizophrenia relative to other mental disorders: evidence for increased fertility in men despite decreased marital rate. Acta Psychiatr Scand 1995;91:222-228.

57. Srinivasan TN, Padmavati R. Fertility and schizophrenia: evidence for increased fertility in the relatives of schizophrenic patients. Acta Psychiatr Scand 1997;96:260-264.

58. Erlenmeyer-Kimling L, Nicol S, Rainer JD, Deming E. Changes in fertility rates of schizophrenic patients in New York. Am J Psychiatry 1969; 125:916-927.

59. Howard LM, Kumar C, Leese M, Thornicroft G. The general fertility rate in women with psychotic disorders. Am J Psychiatry 2002;159: 991-997.

60. Sullivan RJ, Allen JS. Natural selection and schizophrenia. Behav Brain Sci 2004;27:865-866.

61. Haukka J, Suvisaari J, Lönnqvist J. Fertility of patients with schizophrenia, their siblings, and the general population: a cohort study from 1950 to 1959 in Finland. Am J Psychiatry 2003;160:460-463.

62. Svensson AC, Lichtenstein P, Sandin S, Hultman CM. Fertility of firstdegree relatives of patients with schizophrenia: a three generation perspective. Schizophr Res 2007;91:238-245.

63. de Girolamo G, Bassi M, Neri G, Ruggeri M, Santone G, Picardi A. The current state of mental health care in Italy: problems, perspectives, and lessons to learn. Eur Arch Psychiatry Clin Neurosci 2007;257:83-91.

64. Huxley J, Mayr E, Osmond H, Hoffer A. Schizophrenia as a genetic morphism. Nature 1964;204:220-221.

65. Odegaard F. Mortality in Norwegian mental hospitals from 1916 to 1933. Acta Psychiatr Scand 1936;11:323-356.

66. Commissioners in Lunacy for England and Wales. Annual Report. London: HMSO; 1909.

67. Jablensky A, Lawrence D. Schizophrenia and cancer: is there a need to invoke a protective gene? Arch Gen Psychiatry 2001;58:579-580.

68. Gulbinat W, Dupont A, Jablensky A, Jensen OM, Marsella A, Nakane Y, et al. Cancer incidence of schizophrenic patients. Results of record linkage studies in three countries. Br J Psychiatry Suppl 1992;18:75-83.

69. de Leon J, Diaz FJ. A meta-analysis of worldwide studies demonstrates an association between schizophrenia and tobacco smoking behaviors. Schizophr Res 2005;76:135-157.

70. Lohr JB, Flynn K. Smoking and schizophrenia. Schizophr Res 1992;8:93102.

71. Harris JE, Thun MJ, Mondul AM, Calle EE. Cigarette tar yields in rela- tion to mortality from lung cancer in the cancer prevention study II prospective cohort, 1982-8. BMJ 2004;328:72

72. Brown S, Birtwistle J, Roe L, Thompson C. The unhealthy lifestyle of people with schizophrenia. Psychol Med 1999;29:697-701.

73. Cargiulo T. Understanding the health impact of alcohol dependence. Am J Health Syst Pharm 2007;64:S5-S11.

74. Cradock-O'Leary J, Young AS, Yano EM, Wang M, Lee ML. Use of general medical services by VA patients with psychiatric disorders. Psychiatr Serv 2002;53:874-878.

75. Band PR, Le ND, Fang R, Deschamps M, Gallagher RP, Yang P. Identification of occupational cancer risks in British Columbia. A population-based case-control study of 995 incident breast cancer cases by menopausal status, controlling for confounding factors. J Occup Environ Med 2000;42:284-310.

76. Band PR, Le ND, MacArthur AC, Fang R, Gallagher RP. Identification of occupational cancer risks in British Columbia: a population-based case-control study of 1129 cases of bladder cancer. J Occup Environ Med 2005;47:854-858.

77. Csatary LK. Chlorpromazines and cancer. Lancet 1972;2:338-339.

78. Driscoll JS, Melnick NR, Quinn FR, Lomax N, Davignon JP, Ing R, et al. Psychotropic drugs as potential antitumor agents: a selective screening study. Cancer Treat Rep 1978;62:45-74.

79. Dalton SO, Johansen C, Poulsen AH, Nørgaard M, Sørensen HT, McLaughlin JK, et al. Cancer risk among users of neuroleptic medication: a population-based cohort study. Br J Cancer 2006;95:934-939.

80. Mothlagh PB, Henriksson R, Grankvist K. Chlorpromazine enhancement of epirubicin cytotoxicity in vitro: effects on plasma membrane and DNA damage. Drug Metabol Drug Interact 1992;10:169-176.

81. Torrey EF. Prostate cancer and schizophrenia. Urology 2006;68:12801283.

82. Steiner MS, Raghow S, Neubauer BL. Selective estrogen receptor modulators for the chemoprevention of prostate cancer. Urology 2001;57:68-72.

83. Mortimer AM. Relationship between estrogen and schizophrenia. Expert Rev Neurother 2007;7:45-55.

84. Halbreich U, Kinon BJ, Gilmore JA, Kahn LS. Elevated prolactin levels in patients with schizophrenia: mechanisms and related adverse effects. Psychoneuroendocrinology 2003;28:53-67.

85. Jeste DV, Gladsjo JA, Lindamer LA, Lacro JP. Medical comorbidity in schizophrenia. Schizophr Bull 1996;22:413-430.

86. Levav I, Lipshitz I, Novikov I, Pugachova I, Kohn R, Barchana M, et al. Cancer risk among parents and siblings of patients with schizophrenia. Br J Psychiatry 2007;190:156-161.

87. Dalton SO, Laursen TM, Mellemkjaer L, Johansen C, Mortensen PB. Risk for cancer in parents of patients with schizophrenia. Am J Psychiatry 2004;161:903-908.

88. Dong C, Hemminki K. Modification of cancer risks in offspring by sibling and parental cancers from 2,112,616 nuclear families. Int J Cancer 2001;92:144-150.

89. Imsland AK, Eldon BJ, Arinbjarnarson S, Egilsson V, Tulinius H, Tryggvadóttir L, et al. Genetic epidemiologic aspects of gastric cancer in Iceland. J Am Coll Surg 2002;195:181-186; discussion 186-187.

90. Matikaine MP, Pukkala E, Schleutker J, Tammela TL, Koivisto P, Sankila $\mathrm{R}$, et al. Relatives of prostate cancer patients have an increased risk of prostate and stomach cancers: a population-based, cancer registry study in Finland. Cancer Causes Control 2001;12:223-230.

91. Kerber RA, O’Brien E. A cohort study of cancer risk in relation to family histories of cancer in the Utah population database. Cancer 2005; 103:1906-1915.

92. Li X, Hemminki K. Inherited predisposition to early onset lung cancer according to histological type. Int J Cancer 2004;112:451-457.

93. Lynch HT, de la Chapelle A. Genetic susceptibility to non-polyposis colorectal cancer. J Med Genet 1999;36:801-818.

94. Lynch HT, de la Chapelle A. Hereditary colorectal cancer. N Engl J Med 2003;348:919-932.

95. Lewis DA, Levitt P. Schizophrenia as a disorder of neurodevelopment. 
Annu Rev Neurosci 2002;25:409-432.

96. Portin P, Alanen YO. A critical review of genetic studies of schizophrenia. I. Epidemiological and brain studies. Acta Psychiatr Scand 1997; 95:1-5.

97. Abel KM, Allin MP, Jirtle RL. Schizophrenia, cancer and imprinting: early nutritional influences. Br J Psychiatry 2006;188:394.

98. Tsankova N, Renthal W, Kumar A, Nestler EJ. Epigenetic regulation in psychiatric disorders. Nat Rev Neurosci 2007;8:355-367.

99. Owen MJ, Craddock N, O’Donovan MC. Schizophrenia: genes at last? Trends Genet 2005;21:518-525.

100. DeLisi L, Shaw SH, Crow TJ, Shields G, Smith AB, Larach VW, et al. A genome-wide scan for linkage to chromosomal regions in 382 sibling pairs with schizophrenia or schizoaffective disorder. Am J Psychiatry 2002;159:803-812.

101. Maier W, Zobel A, Kühn KU. Clinical impact of recently detected susceptibility genes for schizophrenia. Dialogues Clin Neurosci 2006;8: 79-84.

102. Foster HD, Hoffer A. Schizophrenia and cancer: the adrenochrome balanced morphism. Med Hypotheses 2004;62:415-419.

103. Keller MC, Miller G. Resolving the paradox of common, harmful, heritable mental disorders: which evolutionary genetic models work best? Behav Brain Sci 2006;29:385-404; discussion 405-452.

104. Mittal VA, Ellman LM, Cannon TD. Gene-environment interaction and covariation in schizophrenia: the role of obstetric complications. Schizophr Bull 2008;34:1083-1094.

105. Preti A, Miotto P. Genetics, perinatal insult, and schizophrenia: the mechanism underlying an increased prevalence of perinatal complications among individuals with a diagnosis of schizophrenia? Curr Psychiatry Rev 2005;1:139-150.

106. Boksa P, El-Khodor BF. Birth insult interacts with stress at adulthood to alter dopaminergic function in animal models: possible implications for schizophrenia and other disorders. Neurosci Biobehav Rev 2003;27: 91-101.

107. Engel SA, Erichsen HC, Savitz DA, Thorp J, Chanock SJ, Olshan AF. Risk of spontaneous preterm birth is associated with common proinflammatory cytokine polymorphisms. Epidemiology 2005;16:469-477.

108. Fatemi SH, Emamian ES, Kist D, Sidwell RW, Nakajima K, Akhter P, et al. Defective corticogenesis and reduction in Reelin immunoreactivity in cortex and hippocampus of prenatally infected neonatal mice. Mol Psychiatry 1999;4:145-154.

109. Geddes JR, Verdoux H, Takei N, Lawrie SM, Bovet P, Eagles JM, et al. Schizophrenia and complications of pregnancy and labor: an individual patient data meta-analysis. Schizophr Bull 1999;25:413-423.

110. Kipnis J, Yoles E, Schori H, Hauben E, Shaked I, Schwartz M. Neuronal survival after CNS insult is determined by a genetically encoded autoimmune response. J Neurosci 2001;21:4564-4571.

111. Friedman EA, Neff RK. Labor and Delivery Impact on Offspring. Littleton, MA: PSG Publication; 1987.

112. Paneth N, Stark RI. Cerebral palsy and mental retardation in relation to indicators of perinatal asphyxia. An epidemiologic overview. Am J Obstet Gynecol 1983;147:960-966.

113. Clarke MC, Harley M, Cannon M. The role of obstetric events in schizophrenia. Schizophr Bull 2006;32:3-8.

114. Isohanni M, Miettunen J, Mäki P, Murray GK, Ridler K, Lauronen E, et al. Risk factors for schizophrenia. Follow-up data from the Northern Finland 1966 Birth Cohort Study. World Psychiatry 2006;5:168-171.

115. Hollister JM, Laing P, Mednick SA. Rhesus incompatibility as a risk factor for schizophrenia in male adults. Arch Gen Psychiatry 1996;53: 19-24.

116. Palmer CG, Turunen JA, Sinsheimer JS, Minassian S, Paunio T, Lönnqvist J, et al. RHD maternal-fetal genotype incompatibility increases schizophrenia susceptibility. Am J Hum Genet 2002;71:1312-1319.

117. Walshe M, McDonald C, Taylor M, Zhao J, Sham P, Grech A, et al. Obstetric complications in patients with schizophrenia and their unaffected siblings. Eur Psychiatry 2005;20:28-34.
118. Preti A, Cardascia L, Zen T, Marchetti M, Favaretto G, Miotto P. Risk for obstetric complications and schizophrenia. Psychiatry Res 2000;96: 127-139.

119. Ohara K, Tanabu S, Yoshida K, Sato Y, Shibuya H. Obstetric complications in siblings of Japanese schizophrenics: data from the Maternal and Child Health Handbook. Prog Neuropsychopharmacol Biol Psychiatry 2005;29:617-620.

120. Preti A, Miotto P, Zen T. Perinatal complications, genetic risk and schizophrenia. Acta Psychiatr Scand 1998;97:381-383.

121. McNeil TF, Cantor-Graae E, Torrey EF, Sjöström K, Bowler A, Taylor E, et al. Obstetric complications in histories of monozygotic twins discordant and concordant for schizophrenia. Acta Psychiatr Scand 1994;89: 196-204.

122. Feinberg I. Schizophrenia: caused by a fault in programmed synaptic elimination during adolescence? J Psychiatr Res 1982;17:319-334.

123. Walker E, Bollini AM. Pubertal neurodevelopment and the emergence of psychotic symptoms. Schizophr Res 2002;54:17-23.

124. Catts VS, Catts SV. Apoptosis and schizophrenia: is the tumour suppressor gene, p53, a candidate susceptibility gene? Schizophr Res 2000; 41:405-415.

125. Park JK, Lee HJ, Kim JW, Park YH, Lee SS, Chang HI, et al. Differences in $\mathrm{p} 53$ gene polymorphisms between Korean schizophrenia and lung cancer patients. Schizophr Res 2004;67:71-74.

126. Cui DH, Jiang KD, Jiang SD, Xu YF, Yao H. The tumor suppressor adenomatous polyposis coli gene is associated with susceptibility to schizophrenia. Mol Psychiatry 2005;10:669-677.

127. Morelli C, Karayianni E, Magnanini C, Mungall AJ, Thorland E, Negrini $\mathrm{M}$, et al. Cloning and characterization of the common fragile site FRA6F harboring a replicative senescence gene and frequently deleted in human tumors. Oncogene 2002;21:7266-7276.

128. Britsch S. The neuregulin-I/ErbB signaling system in development and disease. Adv Anat Embryol Cell Biol 2007;190:1-65.

129. Falls DL. Neuregulins: functions, forms, and signaling strategies. Exp Cell Res 2003;284:14-30.

130. Bjarnadottir M, Misner DL, Haverfield-Gross S, Bruun S, Helgason VG, Stefansson H, et al. Neuregulin1 (NRG1) signaling through Fyn modulates NMDA receptor phosphorylation: differential synaptic function in NRG1+/- knock-outs compared with wild-type mice. J Neurosci 2007; 27:4519-4529.

131. Roesler R, Henriques JA, Schwartsmann G. Gastrin-releasing peptide receptor as a molecular target for psychiatric and neurological disorders. CNS Neurol Disord Drug Targets 2006;5:197-204.

132. Olincy A, Leonard S, Young DA, Sullivan B, Freedman R. Decreased bombesin peptide response to cigarette smoking in schizophrenia. Neuropsychopharmacology 1999;20:52-59.

133. Kinkead B, Nemeroff CB. Neurotensin, schizophrenia, and antipsychotic drug action. Int Rev Neurobiol 2004;59:327-349.

134. Perkins DO, Jeffries CD, Jarskog LF, Thomson JM, Woods K, Newman $\mathrm{MA}$, et al. microRNA expression in the prefrontal cortex of individuals with schizophrenia and schizoaffective disorder. Genome Biol 2007;8: R27.

135. Riley DE, Krieger JN. Short tandem repeat (STR) replacements in UTRs and introns suggest an important role for certain STRs in gene expression and disease. Gene 2005;344:203-211.

136. Juvonen H, Reunanen A, Haukka J, Muhonen M, Suvisaari J, Arajärvi $\mathrm{R}$, et al. Incidence of schizophrenia in a nationwide cohort of patients with type 1 diabetes mellitus. Arch Gen Psychiatry 2007;64:894-899.

137. Mors O, Mortensen PB, Ewald H. A population-based register study of the association between schizophrenia and rheumatoid arthritis. Schizophr Res 1999;40:67-74.

138. Torrey EF, Yolken RH. The schizophrenia-rheumatoid arthritis connection: infectious, immune, or both? Brain Behav Immun 2001;15:401410.

139. Klimkeit EI, Bradshaw JL. Anomalous lateralisation in neurodevelopmental disorders. Cortex 2006;42:113-116. 
140. Preti A, Sardu C, Piga A. Mixed-handedness is associated with the reporting of psychotic-like beliefs in a non-clinical Italian sample. Schizophr Res 2007;92:15-23.

141. Preti A, Lai A, Serra M, Zurrida GG. Mixed handedness prevails among children and adolescents with infantile asthma and diabetes. Pediatr Allergy Immunol 2008;19:769-772.

142. Strous RD, Shoenfeld Y. Schizophrenia, autoimmunity and immune system dysregulation: a comprehensive model updated and revisited. J Autoimmun 2006;27:71-80.

143. Yovel G, Sirota P, Mazeh D, Shakhar G, Rosenne E, Ben-Eliyahu S. Higher natural killer cell activity in schizophrenic patients: the impact of serum factors, medication, and smoking. Brain Behav Immun 2000;14:153169.

144. Peebles KA, Lee JM, Mao JT, Hazra S, Reckamp KL, Krysan K, et al. Inflammation and lung carcinogenesis: applying findings in prevention and treatment. Expert Rev Anticancer Ther 2007;7:1405-1421.

145. Rasmussen HB, Timm S, Wang AG, Søeby K, Lublin H, Fenger M, et al. Association between the CCR5 32-bp deletion allele and late onset of schizophrenia. Am J Psychiatry 2006;163:507-511.

146. St-Gelais F, Jomphe C, Trudeau LE. The role of neurotensin in central nervous system pathophysiology: what is the evidence? J Psychiatry Neurosci 2006;31:229-245.

147. Geroldi D, Emanuele E, Martinelli V, Pesenti S. Schizophrenia and cancer risk: can the CCR5-delta 32 chemokine receptor gene mutation play a role? Med Hypotheses 2006;67:427-428.

148. Lasky JL, Wu H. Notch signaling, brain development, and human disease. Pediatr Res 2005;57:104R-109R.

149. Teunis MA, Kavelaars A, Voest E, Bakker JM, Ellenbroek BA, Cools AR, et al. Reduced tumor growth, experimental metastasis formation, and angiogenesis in rats with a hyperreactive dopaminergic system. FASEB J 2002;16:1465-1467.

150. Hashimoto K, Ishiwata K. Sigma receptor ligands: possible application as therapeutic drugs and as radiopharmaceuticals. Curr Pharm Des 2006; 12:3857-3876.

151. Nicodemus KK, Marenco S, Batten AJ, Vakkalanka R, Egan MF, Straub $\mathrm{RE}$, et al. Serious obstetric complications interact with hypoxia-regulated/vascular-expression genes to influence schizophrenia risk. Mol Psychiatry 2008;13:873-877.

152. Schmidt-Kastner R, van Os J, W M Steinbusch H, Schmitz C. Gene regulation by hypoxia and the neurodevelopmental origin of schizophrenia. Schizophr Res 2006;84:253-271.

153. Williams GC. Pleiotropy, natural selection, and the evolution of senescence. Evolution 1957;11:398-411.

154. Crespi B, Summers K, Dorus S. Adaptive evolution of genes underlying schizophrenia. Proc Biol Sci 2007;274:2801-2810.

155. Shi J, Gershon ES, Liu C. Genetic associations with schizophrenia: meta-analyses of 12 candidate genes. Schizophr Res 2008;104:96-107.

156. Jones RE, Lopez KH. Human Reproductive Biology. Burlington, MA: Academic Press; 2006.

157. Crow TJ. The 'big bang' theory of the origin of psychosis and the faculty of language. Schizophr Res 2008;102:31-52.

158. Dalziel SR, Lim VK, Lambert A, McCarthy D, Parag V, Rodgers A, et al. Psychological functioning and health-related quality of life in adulthood after preterm birth. Dev Med Child Neurol 2007;49:597-602.

159. Obel C, Hedegaard M, Henriksen TB, Secher NJ, Olsen J. Psychological factors in pregnancy and mixed-handedness in the offspring. Dev Med Child Neurol 2003;45:557-561.

160. O'Callaghan MJ, Burn YR, Mohay HA, Rogers Y, Tudehope DI. The prevalence and origins of left hand preference in high risk infants, and its implications for intellectual, motor and behavioural performance at four and six years. Cortex 1993;29:617-627.

161. Dragovic M, Hammond G. Handedness in schizophrenia: a quantitative review of evidence. Acta Psychiatr Scand 2005;111:410-419.

162. Sommer I, Ramsey N, Kahn R, Aleman A, Bouma A. Handedness, language lateralisation and anatomical asymmetry in schizophrenia: meta-analysis. Br J Psychiatry 2001;178:344-351.

163. Panksepp J, Panksepp JB. The seven sins of evolutionary psychology. Evolution Cognition 2000;6:108-131.

164. Burdick KE, DeRosse P, Kane JM, Lencz T, Malhotra AK. Association of genetic variation in the MET proto-oncogene with schizophrenia and general cognitive ability. Am J Psychiatry 2010;167:436-443.

165. Rybakowski JK. Matrix metalloproteinase-9 (MMP9)-a mediating enzyme in cardiovascular disease, cancer, and neuropsychiatric disorders. Cardiovasc Psychiatry Neurol 2009;2009:904836.

166. Walsh T, McClellan JM, McCarthy SE, Addington AM, Pierce SB, Cooper GM, et al. Rare structural variants disrupt multiple genes in neurodevelopmental pathways in schizophrenia. Science 2008;320: 539-543.

167. Sun J, Jia P, Fanous AH, van den Oord E, Chen X, Riley BP, et al. Schizophrenia gene networks and pathways and their applications for novel candidate gene selection. PLoS One 2010;5:e11351.

168. Lewis G, David A, Andréasson S, Allebeck P. Schizophrenia and city life. Lancet 1992;340:137-140.

169. Pedersen CB, Mortensen PB. Evidence of a dose-response relationship between urbanicity during upbringing and schizophrenia risk. Arch Gen Psychiatry 2001;58:1039-1046.

170. Kirkbride JB, Fearon P, Morgan C, Dazzan P, Morgan K, Tarrant J, et al. Heterogeneity in incidence rates of schizophrenia and other psychotic syndromes: findings from the 3-center AeSOP study. Arch Gen Psychiatry 2006;63:250-258.

171. Boydell J, van Os J, McKenzie K, Allardyce J, Goel R, McCreadie RG, et al. Incidence of schizophrenia in ethnic minorities in London: ecological study into interactions with environment. BMJ 2001;323:13361338.

172. Cantor-Graae E, Selten JP. Schizophrenia and migration: a meta-analysis and review. Am J Psychiatry 2005;162:12-24.

173. Fearon P, Kirkbride JB, Morgan C, Dazzan P, Morgan K, Lloyd T, et al. Incidence of schizophrenia and other psychoses in ethnic minority groups: results from the MRC AESOP study. Psychol Med 2006;36: 1541-1550.

174. McGrath JJ, Welham JL. Season of birth and schizophrenia: a systematic review and meta-analysis of data from the Southern Hemisphere. Schizophr Res 1999;35:237-242.

175. Davies G, Welham J, Chant D, Torrey EF, McGrath J. A systematic review and meta-analysis of Northern Hemisphere season of birth studies in schizophrenia. Schizophr Bull 2003;29:587-593.

176. Mednick SA, Machon RA, Huttunen MO, Bonett D. Adult schizophrenia following prenatal exposure to an influenza epidemic. Arch Gen Psychiatry 1988;45:189-192.

177. Bagalkote H, Pang D, Jones P. Maternal influenza and schizophrenia in the offspring. Int J Ment Health 2001;29:3-21.

178. Brown AS, Begg MD, Gravenstein S, Schaefer CA, Wyatt RJ, Bresnahan M. Serologic evidence of prenatal influenza in the etiology of schizophrenia. Arch Gen Psychiatry 2004;61:774-780.

179. Brown AS, Cohen P, Greenwald S, Susser E. Nonaffective psychosis after prenatal exposure to rubella. Am J Psychiatry 2000;157:438-443.

180. Suvisaari J, Haukka J, Tanskanen A, Hovi T, Lönnqvist J. Association between prenatal exposure to poliovirus infection and adult schizophrenia. Am J Psychiatry 1999;156:1100-1102.

181. Brown AS, Schaefer CA, Quesenberry CP Jr, Liu L, Babulas VP, Susser ES. Maternal exposure to toxoplasmosis and risk of schizophrenia in adult offspring. Am J Psychiatry 2005;162:767-773.

182. Torrey EF, Bartko JJ, Lun ZR, Yolken RH. Antibodies to Toxoplasma gondii in patients with schizophrenia: a meta-analysis. Schizophr Bull 2007;33:729-736

183. Koponen H, Rantakallio P, Veijola J, Jones P, Jokelainen J, Isohanni M. Childhood central nervous system infections and risk for schizophrenia. Eur Arch Psychiatry Clin Neurosci 2004;254:9-13.

184. Dalman C, Allebeck P, Gunnell D, Harrison G, Kristensson K, Lewis G, et al. Infections in the CNS during childhood and the risk of subsequent 
psychotic illness: a cohort study of more than one million Swedish subjects. Am J Psychiatry 2008;165:59-65.

185. Susser ES, Lin SP. Schizophrenia after prenatal exposure to the Dutch Hunger Winter of 1944-1945. Arch Gen Psychiatry 1992;49:983-988.

186. St Clair D, Xu M, Wang P, Yu Y, Fang Y, Zhang F, et al. Rates of adult schizophrenia following prenatal exposure to the Chinese famine of 1959-1961. JAMA 2005;294:557-562.

187. Brown AS, Susser ES. Prenatal nutritional deficiency and risk of adult schizophrenia. Schizophr Bull 2008;34:1054-1063.

188. Selten JP, van der Graaf Y, van Duursen R, Gispen-de Wied CC, Kahn RS. Psychotic illness after prenatal exposure to the 1953 Dutch Flood Disaster. Schizophr Res 1999;35:243-245.

189. Mäki P, Veijola J, Rantakallio P, Jokelainen J, Jones PB, Isohanni M. Schizophrenia in the offspring of antenatally depressed mothers: a 31-year follow-up of the Northern Finland 1966 Birth Cohort. Schizophr Res 2004; 66:79-81.

190. Myhrman A, Rantakallio P, Isohanni M, Jones P, Partanen U. Unwantedness of a pregnancy and schizophrenia in the child. Br J Psychiatry 1996;169:637-640.

191. van Os J, Selten JP. Prenatal exposure to maternal stress and subsequent schizophrenia. The May 1940 invasion of The Netherlands. Br J Psychiatry 1998;172:324-326.

192. Beydoun H, Saftlas AF. Physical and mental health outcomes of prenatal maternal stress in human and animal studies: a review of recent evidence. Paediatr Perinat Epidemiol 2008;22:438-466.

193. Rosso IM, Cannon TD, Huttunen T, Huttunen MO, Lönnqvist J, Gasperoni TL. Obstetric risk factors for early-onset schizophrenia in a Finnish birth cohort. Am J Psychiatry 2000;157:801-807.

194. Zornberg GL, Buka SL, Tsuang MT. Hypoxic-ischemia-related fetal/ neonatal complications and risk of schizophrenia and other nonaffective psychoses: a 19-year longitudinal study. Am J Psychiatry 2000;157: 196-202.

195. Rifkin L, Lewis S, Jones P, Toone B, Murray R. Low birth weight and schizophrenia. Br J Psychiatry 1994;165:357-362.

196. Dalman C, Thomas HV, David AS, Gentz J, Lewis G, Allebeck P. Signs of asphyxia at birth and risk of schizophrenia. Population-based casecontrol study. Br J Psychiatry 2001;179:403-408.

197. Wahlbeck K, Forsén T, Osmond C, Barker DJ, Eriksson JG. Association of schizophrenia with low maternal body mass index, small size at birth, and thinness during childhood. Arch Gen Psychiatry 2001; 58:48-52.

198. Buka SL, Tsuang MT, Lipsitt LP. Pregnancy/delivery complications and psychiatric diagnosis. A prospective study. Arch Gen Psychiatry 1993;50: 151-156.

199. Dalman C, Allebeck P, Cullberg J, Grunewald C, Köster M. Obstetric complications and the risk of schizophrenia: a longitudinal study of a national birth cohort. Arch Gen Psychiatry 1999;56:234-240.

200. Cardno AG, Marshall EJ, Coid B, Macdonald AM, Ribchester TR, Davies NJ, et al. Heritability estimates for psychotic disorders: the Maudsley twin psychosis series. Arch Gen Psychiatry 1999;56:162-168.

201. Kringlen E. Twin studies in schizophrenia with special emphasis on concordance figures. Am J Med Genet 2000;97:4-11.

202. Davis KL, Kahn RS, Ko G, Davidson M. Dopamine in schizophrenia: a review and reconceptualization. Am J Psychiatry 1991;148:1474-1486.

203. Kapur S. Psychosis as a state of aberrant salience: a framework linking biology, phenomenology, and pharmacology in schizophrenia. Am J Psychiatry 2003;160:13-23.

204. Gracie A, Freeman D, Green S, Garety PA, Kuipers E, Hardy A, et al. The association between traumatic experience, paranoia and hallucinations: a test of the predictions of psychological models. Acta Psychiatr Scand 2007;116:280-289.

205. Scott J, Chant D, Andrews G, Martin G, McGrath J. Association between trauma exposure and delusional experiences in a large community-based sample. Br J Psychiatry 2007;190:339-343.

206. D'Souza DC. Cannabinoids and psychosis. Int Rev Neurobiol 2007;78: 289-326. 